\title{
Effect of heat treatment and enzymatic protein hydrolysis on the degree of hydrolysis and physicochemical properties of edible bird's nest
}

\author{
${ }^{1 *}$ Amiza, M.A., ${ }^{1}$ Khuzma, D., ${ }^{1}$ Liew, P.S., ${ }^{2}$ Salma Malihah, M. and ${ }^{1}$ Sarbon, N.M. \\ ${ }^{1}$ School of Food Science and Technology, Universiti Malaysia Terengganu, 21030 Kuala Nerus, \\ Terengganu, Malaysia. \\ ${ }^{2}$ Kulliyyah of Science, International Islamic University Malaysia, P.O. Box 141, 25710 Kuantan, Pahang \\ Darul Makmur, Malaysia.
}

Article history:

Received: 5 April 2019

Received in revised form: 19 May 2019

Accepted: 21 May 2019

Available Online: 1 June 2019

\section{Keywords:}

Edible bird's nest,

Heat treatment,

Degree of hydrolysis,

Alcalase ${ }^{\circledR}$,

Physicochemical,

Enzymatic hydrolysis

\section{DOI:}

https://doi.org/10.26656/fr.2017.3(6).149

\begin{abstract}
This study reported the effect of heat treatment and protein enzymatic hydrolysis on the degree of hydrolysis (DH) and physicochemical properties of edible bird's nest (EBN). The EBN samples were subjected to eleven different processing treatments which were control EBN (raw), 30 mins normal boiled EBN (NB30); 30 mins normal boiled EBN followed with protein hydrolysis using $1 \%$ Alcalase ${ }^{\circledR}(\mathrm{NB} 30 \mathrm{H}) ; 60$ mins normal boiled EBN (NB60); 60 mins normal boiled EBN followed with protein hydrolysis using 1\% Alcalase ${ }^{\circledR}(\mathrm{NB} 60 \mathrm{H}) ; 60$ mins slow cooked EBN (SC60); 60 mins slow cooked EBN followed with protein hydrolysis using $1 \%$ Alcalase ${ }^{\circledR}$ (SC60H); 120 mins slow cooked EBN (SC120); 120 mins slow cooked EBN followed with protein hydrolysis using 1\% Alcalase ${ }^{\circledR}(\mathrm{SC} 120 \mathrm{H})$; autoclaved $\mathrm{EBN}$ at $121^{\circ} \mathrm{C}$ for 15 mins (A); autoclaved EBN at $121^{\circ} \mathrm{C}$ for 15 mins followed with protein hydrolysis using $1 \%$ Alcalase ${ }^{\circledR}(\mathrm{AH})$. The treated EBN samples were then freeze dried prior to further analysis. This study found that heat treatment alone produced EBN sample with lower DH $(5.84 \%$ to $14.54 \%)$ as compared to those undergone combined heat treatment and enzymatic protein hydrolysis $(12.16 \%$ to $22.59 \%)$. EBN samples in this study gave solubility of $4.52-87.11 \%$, water holding capacity of $3.82-17.9 \mathrm{~mL} / \mathrm{g}$, oil holding capacity of $4.87-7.65 \mathrm{~mL} / \mathrm{g}$, emulsifying capacity of $18.08-56.15 \%$, emulsifying stability of $12.03-50.34 \%$, foaming capacity of $0.75-359 \%$, foaming stability (after 60 mins) of $58.89-96.39 \%$ and viscosity (for $1-10 \%$ EBN sample) of $26.67-7526.67 \mathrm{mPa}$.s. It was found that there was a positive correlation between DH and solubility, emulsifying capacity and emulsifying stability of EBN samples. However, a negative correlation was found between DH and water holding capacity and viscosity of EBN samples. Furthermore, there was no correlation between DH and oil holding capacity and colour profiles. Thus, this study shows that heat treatment and enzymatic hydrolysis of EBN can be tailored to achieve a certain degree of hydrolysis and physicochemical properties.
\end{abstract}

\section{Introduction}

Edible bird's nests $(\mathrm{EBN})$ are substances produced from the salivary secretion of certain swiftlets. EBN consist largely of a mucin-like substance called glycoprotein (Ma and Liu, 2012). EBN is a good source of high-quality protein $(61.5-62 \%)$ (Norhayati et al., 2010; Ma and Liu, 2012). According to Roussel et al. (1988), EBN contains hundreds of carbohydrate chains attached to the peptide by O-glycosidic linkages between $\mathrm{N}$-acetylgalactosamine and a hydroxylated amino acid made from serine and threonine. EBN has been consumed over many decades, and many health claims have been made, ranging from enhancing complexion due to the presence of epidermal growth factor, alleviating asthma, strengthening the immune system and neuroprotective effect against 6-OHDA-induced degeneration of dopaminergic neurons, particularly through inhibition of apoptosis (Kong et al., 1987; Lim and Cranbrook, 2002; Yew et al., 2014). Traditionally in Chinese culture, EBN drink is a type of delicate food prepared by double boiling the EBN with rock sugar. However, double boiled EBN has low solubility (Amiza et al., 2019). Even after 2 hrs of slow cooking, the presence of short EBN strands is still visible. The solubility of food protein is important in order to fully utilize it in the food industry. Protein solubility affects 
protein functionality especially thickening, foaming, emulsifying and gelling. Insoluble proteins have very limited uses in the food industry. Besides, the expensive price of EBN (the local price of cleaned EBN is RM 6,000 to RM 8,000 per $\mathrm{kg}$ ) (Mohamad Shukri et al., 2018) calls for maximum utilization and benefits of EBN to be explored. A fundamental understanding of the physicochemical properties of proteins and their changes during processing is essential in the improvement of protein performance or development of new protein ingredients (Damodaran and Parkin, 2017). Generally, protein functionalities is governed by its physical and chemical properties including size, shape, amino acid composition, and sequence, net charge and distribution, hydrophobicity/hydrophilic ratio, secondary, tertiary and quaternary structures, molecular flexibility/ rigidity, and ability to interact with other components (Damodaran and Parkin, 2017). Heat treatment causes alteration in protein native structure resulting in the unfolding of protein and protein surface exposure (Teodorowicz et al., 2017). Extensive denaturation of proteins often results in insolubilization, which can impair those functional properties that are dependent on solubility (Murano, 2003). Conversely, partial denaturation of protein often improves digestibility and biological availability of essential amino acids (Damodaran and Parkin, 2017). Besides, enzymatic protein hydrolysis is commonly used to modify the nutritional, physicochemical, functional, digestibility, sensory and bioactive properties of protein, as well as to reduce allergenic and antinutritional compounds (Chalamaiah et al., 2012; Tavano, 2013). The properties of protein hydrolysate are affected by the degree of hydrolysis (DH) (Panyam and Kilara, 1996). Thus, heat treatment and enzymatic protein hydrolysis may help to increase EBN solubility and thus maximize its functionality, digestibility and bioactivity. Optimization of enzymatic protein hydrolysis conditions of EBN (normal boiled for $30 \mathrm{~min}$ ) using Alcalase ${ }^{\circledR}$ has been reported previously (Amiza et al., 2019). Despite of the vast literatures on EBN, there is a lack of information available on the effects of different processing on the degree of hydrolysis and physicochemical properties of EBN. Effect of heat treatment and/or protein hydrolysis on physicochemical properties and/or degree of hydrolysis have been studied extensively for various protein sources such as milk (Raikos, 2010), acid whey protein concentrate (Liao and Mangino, 1987), grass carp skin hydrolysate (Wasswa et al., 2007) and silver catfish frame hydrolysate (Amiza et al., 2013). This information is essentially important to incorporate EBN in food, nutraceutical or cosmeceutical products with desirable degree of hydrolysis and physicochemical properties. Thus, the objective of this study was to determine the effect of heat treatment and enzymatic protein hydrolysis on the degree of hydrolysis (DH) and physicochemical properties of EBN.

\section{Materials and Methods}

Raw, unprocessed edible white bird's nest (EBN) (from Aerodramus fuciphagus species) was purchased from a swiftlet farmer in Gong Badak, Kuala Terengganu. Commercial food-grade enzyme, Alcalase ${ }^{\circledR}$ $2.4 \mathrm{~L}$ was purchased from Novo Industries $\mathrm{A} / \mathrm{S}$ Bagsvaerd, Denmark. Other chemical reagents used were of analytical grade.

\subsection{EBN cleaning}

Raw-unprocessed EBN was cleaned as described by Lim and Cranbrook (2002) with some modification. Raw -unprocessed EBN was first soaked in tap water for 8 hrs. Then, it was washed and rinsed several times to get rid of contaminants (guano, eggshells, dust) and swiftlet feathers. Fine feathers were then plucked manually using a fine tips tweezers with the aid of illumination magnifying lens. Then, the wet cleaned EBN was kept in a plastic container in a freezer $\left(-20^{\circ} \mathrm{C}\right)$ until further use.

\subsection{EBN treatments}

The thawed, wet, cleaned EBN was subjected to eleven different processing treatments $(n=2)$. The EBN samples prepared included control EBN (raw), 30 mins normal boiled EBN (NB30); 30 mins normal boiled EBN followed with protein hydrolysis using $1 \%$ Alcalase $\mathbb{}$ $(\mathrm{NB} 30 \mathrm{H}) ; 60$ mins normal boiled EBN (NB60); 60 mins normal boiled EBN followed with protein hydrolysis using 1\% Alcalase ${ }^{\circledR}(\mathrm{NB} 60 \mathrm{H}) ; 60$ mins slow cooked EBN (SC60); 60 mins slow cooked EBN followed with protein hydrolysis using $1 \%$ Alcalase ${ }^{\circledR}(\mathrm{SC} 60 \mathrm{H}) ; 120$ min slow cooked EBN (SC120); 120 mins slow cooked EBN followed with protein hydrolysis using $1 \%$ Alcalase ${ }^{\circledR}(\mathrm{SC} 120 \mathrm{H})$; autoclaved EBN at $121^{\circ} \mathrm{C}$ for 15 mins (A); autoclaved $\mathrm{EBN}$ at $121^{\circ} \mathrm{C}$ for $15 \mathrm{mins}$ followed with protein hydrolysis using $1 \%$ Alcalase ${ }^{\circledR}$ (AH). Normal boiling was carried out using a hotplate (Labmart HTS-1003, Copens Scientific, South Korea), while slow cooking was employed by using a slow cooker (Pensonic PSC-182, Pensonic, Malaysia) at high mode $(120 \mathrm{~W})$.

For five treatments involving heat treatment only, raw cleaned EBN was homogenized with distilled water (1:4 ratio) and heat treated accordingly as required by the experimental design. However, for preparation of EBN samples using a combination of heat treatment and enzymatic protein hydrolysis using $1 \%$ Alcalase ${ }^{\circledR}(5$ treatments), information on the crude protein content of EBN is needed first. Information on the protein content 
of raw cleaned EBN was first determined using the Kjeldahl method (AOAC, 2000). It was found that the raw, wet cleaned EBN contained $6.56 \%$ protein. The calculations of mass of EBN, distilled water and Alcalase ${ }^{\circledR}$ to be used in each run of enzymatic protein hydrolysis were employed according to Amiza et al. (2014). EBN sample was homogenized with distilled water (as previously calculated) and then heat treated accordingly and then allowed to cool to room temperature. The EBN protein hydrolysis was performed according to the procedure of Bhaskar and Mahendrakar (2008). For further enzymatic hydrolysis, $\mathrm{pH}$ adjustment was carried out using $1 \mathrm{M} \mathrm{NaOH}$ to adjust the $\mathrm{pH}$ to 8.5 (the mass of I $\mathrm{M} \mathrm{NaOH}$ used was also considered as part of mass of distilled water). Next, the mass of distilled water in the heat treated EBN solution was adjusted accordingly with distilled water (according to the mass of distilled water needed) and the mixture was then heated in a water bath (Techne TE-10D, Bibby Scientific Ltd, Staffordshire, OSA, UK) until the temperature reached $55^{\circ} \mathrm{C}$. Then, Alcalase ${ }^{\circledR}(1 \%$ enzyme to substrate ratio) was mixed into the EBN solution. Enzymatic protein hydrolysis was started immediately for $60 \mathrm{mins}$ in the water bath. Upon completion of hydrolysis, the process was terminated by heating the hydrolysate sample at $85^{\circ} \mathrm{C}$ for $20 \mathrm{mins}$ in order to inactivate the Alcalase ${ }^{\circledR}$ activity. Then, the EBN sample from each treatment was frozen $\left(-20^{\circ} \mathrm{C}\right)$ before freeze-drying. The lyophilized EBN was ground with mortar and pestle to produce lyophilized EBN powder. The EBN powder samples were stored in airtight containers at room temperature until further analysis.

\subsection{Determination of degree of hydrolysis (DH)}

The degree of hydrolysis (DH) of EBN powder was determined by using the trichloroacetic acid (TCA) method as described by Hoyle and Merritt (1994). Total nitrogen content was determined by analyzing $0.5 \mathrm{~g}$ of freeze-dried EBN powder using the Kjeldahl method. As for the determination of $10 \%$ TCA soluble nitrogen, 0.5 $\mathrm{g}$ of freeze-dried EBN powder was added to $10 \mathrm{~mL}$ of distilled water. Then, $10 \mathrm{~mL}$ of $20 \%(\mathrm{w} / \mathrm{v})$ TCA was mixed with the sample. The sample was left to stand for $30 \mathrm{~min}$ for precipitation. Later, the sample was centrifuged (High-speed centrifuges model 1580R, Gyrozen Co., Ltd, Korea) at 4000 rpm for 15 mins. The resulting supernatant was filtered and analysed using the Kjeldahl method (AOAC, 2000). DH is defined as the percentage ratio between the number of peptide bonds cleaved and the total number of peptide bonds in the sample (Adler-Nissen, 1986). DH was computed as follows:

$$
\% D H=\frac{10 \% \text { TCA soluble } \mathrm{N} \text { in the sample }}{\text { Total } \mathrm{N} \text { in the sample }} \times 100
$$

\subsection{Determination of physicochemical properties}

\subsubsection{Colour}

The colour of lyophilized EBN powder was determined using a colorimeter (Minolta Chroma Meter CR 300, Osaka, Japan).

\subsubsection{Viscosity}

Viscosity of freeze-dried EBN powder was determined by using Brookfield viscometer (Brookfield DV-II+ Programmable Viscometer, Brookfield Engineering Laboratories, Inc, Middleboro, MA, USA) using a helipath spindles TD-94. EBN stock solution $(10 \% \mathrm{w} / \mathrm{v})$ was prepared for each protein hydrolysate using distilled water as the solvent. Working protein solutions for desired concentration $(1,3,5,7$ and $10 \% \mathrm{w} /$ $\mathrm{v}, 20 \mathrm{~mL}$ each) were prepared from appropriate stock solutions. Then, viscosity was determined using steady stress. The viscosity measurement range of a Brookfield programmable viscometer DV-II+ appears in the unit of mPa.s. The spindle groove was immersed in the protein solution. A fixed volume of protein solution was measured each time and the spindle depth will be kept constant throughout the measurements. The measurements were reported at a spindle speed of 100 rpm.

\subsubsection{Solubility}

Protein solubility of lyophilized EBN powder was determined by using nitrogen solubility index (NSI) as described by Morr et al. (1985). EBN hydrolysate (0.25 g) was first dispersed in $25 \mathrm{~mL}$ of $0.1 \mathrm{M} \mathrm{NaCl}$. The mixture was then stirred at room temperature for $60 \mathrm{mins}$ prior to centrifugation (4000 rpm, $30 \mathrm{mins}$ ). The supernatant was filtered using Whatman No. 1 filter paper. The nitrogen contents in the total fraction and in the soluble fraction were analysed by using the Kjeldahl method (AOAC, 2000). The NSI was determined by using the following formula:

Nitrogen solubility $(\%)=\frac{\text { amount of nitrogen in supernatant }}{\text { total amount of nitrogen in sample }} \times 100 \%$

\subsubsection{Water holding capacity (WHC)}

Water holding capacity of lyophilized EBN powder was determined using the centrifugation method outlined by Diniz and Martin (1997). EBN hydrolysate (0.5 g) was dissolved with $20 \mathrm{~mL}$ of distilled water in centrifuge tubes and vortexed for $30 \mathrm{~s}$. The dispersion was allowed to stand at room temperature for $6 \mathrm{hrs}$ prior to centrifugation (4000 rpm, 15 mins). The supernatant was filtered with Whatman No. 1 filter paper and the volume retrieved was accurately measured. The difference between the initial volume of distilled water added and the volume retrieved after centrifugation was taken as the 
volume of water absorbed. WHC was reported as $\mathrm{ml}$ of water absorbed per gram of sample.

\subsubsection{Oil holding capacity (OHC)}

Oil holding capacity of lyophilized EBN powder was determined using the methodology outlined by Haque and Mozaffar (1992). EBN hydrolysate $(0.5 \mathrm{~g})$ was weighed into centrifuge tubes and thoroughly mixed with $10 \mathrm{~mL}$ of corn oil using a vortex mixer for $30 \mathrm{~s}$. Then, the mixture was allowed to stand at room temperature for $30 \mathrm{~min}$, followed by centrifugation ( $3000 \mathrm{rpm}, 30 \mathrm{mins}$ ). Immediately after centrifugation, the supernatant was carefully poured into a $10 \mathrm{~mL}$ graduated cylinder and the volume was recorded. The difference between the initial volume of oil added and the volume retrieved was taken as the volume of oil absorbed. OHC was reported as $\mathrm{ml}$ of oil absorbed per gram of sample.

\subsubsection{Emulsifying capacity (EC) and emulsion stability (ES)}

Emulsifying capacity and emulsion stability of freeze-dried EBN powder were determined following the methods of Neto et al. (2001). EBN hydrolysate $(0.05 \mathrm{~g})$ was first dispersed with $5 \mathrm{~mL}$ distilled water to produce $10 \mathrm{mg} / \mathrm{ml}$ protein dispersion. Then, the dispersion was homogenized with $5 \mathrm{~mL}$ of corn oil at speed $2(10,000 /$ min) for 1 min by using homogenizer (IKA@ T18 Basic, IKA Works Inc., USA). The emulsion was centrifuged at $1100 \mathrm{rpm}$ for $5 \mathrm{~min}$. The height of the emulsion layer and the total content in the tube were determined. The emulsifying capacity was calculated as follows:

Emulsifying capacity $(\%)=\frac{\text { Height of the emulsified layer }}{\text { Height of the total content }} \times 100 \%$

Emulsion stability was determined by heating the emulsion at $55^{\circ} \mathrm{C}$ for 30 mins before centrifuging at 2000 rpm for 5 mins. The emulsifying stability was calculated according to the equation below:

$$
\text { Emulsion stability (\%) }=\frac{\text { Height of the emulsified layer after heating }}{\text { Height of the emulsified layer before heating }} \times 100 \%
$$

\subsubsection{Foaming capacity $(F C)$ and foaming stability (FS)}

Foaming capacity and foam stability of EBN hydrolysate were determined according to the method of Shahidi et al. (1995) with slight modifications. For foaming capacity, $1.5 \mathrm{~g}$ of EBN hydrolysate was dispersed in $50 \mathrm{ml}$ of distilled water and the mixture was homogenized at speed $2(10,000 / \mathrm{min})$ for $1 \mathrm{~min}$ by using a homogenizer (IKA@ T18 Basic, IKA Works Inc., USA). Then, the mixture was poured into a $250 \mathrm{~mL}$ graduated cylinder. The volume was recorded before and after homogenizing. The difference in volume was expressed as the volume of the foam and foaming capacity was expressed as percentage of volume increase upon homogenizing.

$$
\text { Foam capacity }(\%)=\frac{\mathrm{V}_{2}-V_{1}}{V_{1}} \times 100 \%
$$

Where, $\mathrm{V}_{1}=$ initial volume of solution $(\mathrm{mL})$ and $\mathrm{V}_{2}=$ volume of solution after homogenizing $(\mathrm{mL})$

For foam stability, foam volume was measured after $5,10,20,40$ and 60 mins quiescent periods at room temperature. Foam stability was expressed as the percentage of initial foam volume.

\subsection{SDS-PAGE of control, SC60 and SC60H samples}

In order to determine the effect of heat treatment and enzymatic protein hydrolysis on the molecular weight of EBN, SDS-PAGE was carried out on selected EBN samples (control, SC60 and SC60H). Firstly, $0.5 \mathrm{~g}$ of EBN samples were suspended in $50 \mathrm{~mL}$ deionized water and was allowed to stand for $24 \mathrm{hrs}$ at $4^{\circ} \mathrm{C}$. An aliquot of the extract was then heated in a water bath at $70^{\circ} \mathrm{C}$ for an hour, followed by centrifugation at $4000 \mathrm{rpm}$ for 15 mins. The supernatant was filtered using $0.4 \mu \mathrm{m}$ Millipore membrane filtration and stored at $4{ }^{\circ} \mathrm{C}$ prior to loading in sodium dodecyl sulfate polyacrylamide electrophoresis (SDS-PAGE). SDS-PAGE analysis was carried out using $12 \%$ resolving gel and $4 \%$ stacking gel. The EBN sample was suspended in 5\% (w/v) and mixed with 1:1 (v/v) ratio loading buffer. The solution was heated in a $90^{\circ} \mathrm{C}$ water bath for 20 mins and then cooled immediately before loading. Volumes of $20 \mu \mathrm{L}$ of sample and protein standard were loaded into individual wells and run using discontinuous Tris buffer with a constant current setting of $30 \mathrm{~mA}$ and an initial voltage of $150 \mathrm{~V}$ for $15 \mathrm{mins}$ and at $200 \mathrm{~V}$ for another $45 \mathrm{mins}$. After electrophoresis, proteins were stained with $0.1 \%$ (w/v) Coomassie blue G250. Protein markers (11 to 245 $\mathrm{kDa}$ ) were used for molecular weight determination.

\subsection{Data analysis}

All data were reported as mean \pm standard deviation $(\mathrm{n}=2)$ and analysed statistically using One-way ANOVA with significance level at $\mathrm{p}<0.05$ by using Minitab 14 software (Minitab Inc., USA). Significant difference between means of results was determined by using Tukey's multiple comparison test at $\alpha=0.05$. Correlation between degree of hydrolysis and each physicochemical property of EBN was analysed using Pearson correlation test.

\section{Results and discussion}

\subsection{Degree of hydrolysis (DH)}

Table 1 shows the degree of hydrolysis (DH), solubility water holding capacity, oil holding capacity, 
emulsifying capacity and emulsifying stability of lyophilized EBN samples as affected by heat treatment and protein hydrolysis. DH values range from 4.23 $22.39 \%$. The heat treatment alone produced EBN sample with lower DH (5.84\% to $14.54 \%)$ as compared to those undergone combined heat treatment and enzymatic protein hydrolysis $(12.16 \%$ to $22.59 \%)$. Taking into consideration significant difference between treatments, the $\mathrm{DH}$ value in decreasing order was given by $\mathrm{NB} 60 \mathrm{H}$, $\mathrm{NB} 120 \mathrm{H}>\mathrm{AH}>\mathrm{NB} 60>\mathrm{A}, \mathrm{SC120H}>\mathrm{SC} 60 \mathrm{H}>$ NB30, SC120, SC60 > Raw. As expected, the raw EBN gave the lowest $\mathrm{DH}$ (4.23\%). Protein hydrolysis occurs in raw EBN may be due to the possible autolysis of original intact protein with endogenous enzymes prior to cleaning and during the cleaning process. Protein hydrolysis may occur during long hours of soaking and cleaning process of EBN at room temperature.

For the five EBN treatments that only involved heat treatment, the $\mathrm{DH}$ in decreasing order was given by NB60, A > SC120, NB30, SC60. This study showed that there was no significant difference in $\mathrm{DH}$ for $\mathrm{EBN}$ treated with normal boiling for $60 \mathrm{mins}$ (NB60) $(14.54 \%)$ and autoclave at $121^{\circ} \mathrm{C}$ for 15 mins (A) (13.68\%). For SC120 (6.76\%), NB30 (6.52\%) and SC60 (5.84\%), there was no significant difference in $\mathrm{DH}$ among these three heat treatments. The low DH could be attributed to the mild heat treatments applied during slow cooking, whereby the temperature of slow cooking is between $85-96^{\circ} \mathrm{C}$ (Gisslen, 2011), while normal boiling is at $100^{\circ} \mathrm{C}$. This indicates that slow cooking at $60-120$ mins and normal boiling at 60 mins gave similar DH. This study shows that DH of EBN was affected by the extent of heat treatment for extreme end.

In general, for similar heat treatment, Alcalase $(\mathrm{R}-$ hydrolysed EBN samples gave significantly higher DH than the non-hydrolysed samples. For hydrolysed EBN, $\mathrm{NB} 60 \mathrm{H}(22.59 \%)$ and $\mathrm{NB} 30 \mathrm{H}(20.42 \%)$ gave the highest
$\mathrm{DH}$, followed by $\mathrm{AH}(16.85 \%)$ and finally $\mathrm{SC} 120 \mathrm{H}$ (13.82\%) and $\mathrm{SC} 60 \mathrm{H}(12.16 \%)$. The high $\mathrm{DH}$ values in $\mathrm{NB} 60 \mathrm{H}$ and $\mathrm{NB} 30 \mathrm{H}$ could be due to the fact that denatured proteins are more readily hydrolysed by proteases by promoting accessibility of proteases to cleavage sites (Singhal et al., 2012). The DH values in this study were within the similar range reported for the previous study whereby EBN (normal boiled for 30 mins) was hydrolysed using Alcalase ${ }^{\circledR}$ at different hydrolysis parameters (DH of 14.27-37.89\%) (Amiza et al., 2019). They reported a higher $\mathrm{DH}$ of $37.89 \%$ at the optimum condition of protein hydrolysis of EBN with Alcalase ${ }^{\circledR}$ which was obtained at temperature of $64.99^{\circ} \mathrm{C}, \mathrm{pH}$ of 9.46 , hydrolysis time of 179.55 and Alcalase ${ }^{\circledR}$ concentration of $2 \%$. This study showed that DH of EBN was affected by heat treatment and enzymatic protein hydrolysis.

\subsection{Physicochemical properties}

\subsubsection{Solubility}

Protein solubility depends on hydrophilicity and electrostatic repulsions (Tavano, 2013). The solubility of lyophilized EBN varied with different treatments ranging from $4.52-87.11 \%$ (Table 1). Taking into consideration significant difference between treatments, the solubility of EBN in decreasing order was given by $\mathrm{NB} 60 \mathrm{H}, \mathrm{AH}>$ $\mathrm{NB} 30 \mathrm{H}>\mathrm{A}, \mathrm{SC} 120 \mathrm{H}, \mathrm{SC} 60 \mathrm{H}>\mathrm{NB} 60, \mathrm{NB} 30, \mathrm{SC} 120>$ SC60 > Raw. For the five EBN treatments that undergone heat treatment only, the solubility in decreasing order was given by A > NB60, NB30, SC120 $>$ SC60. The highest solubility was given by A $(60.39 \%)$ and the lowest solubility was given by SC60 (18.84\%). For SC120 (25.31\%), NB30 (24.94\%) and NB60 $(30.4 \%)$, there was no significant difference in solubility among these three heat treatments.

For similar heat treatment, Alcalase $\AA$-hydrolysed EBN samples always gave higher solubility than that of

Table 1. Degree of hydrolysis, solubility water holding capacity, oil holding capacity, emulsifying capacity and emulsifying stability of lyophilized EBN samples as affected by heat treatment and protein hydrolysis

\begin{tabular}{cccccccc}
\hline Treatments & $\begin{array}{c}\text { Degree of } \\
\text { hydrolysis } \\
(\%)\end{array}$ & $\begin{array}{c}\text { Solubility } \\
(\%)\end{array}$ & $\begin{array}{c}\text { Water holding } \\
\text { capacity }(\mathrm{mL} / \mathrm{g})\end{array}$ & $\begin{array}{c}\text { Oil holding } \\
\text { capacity }(\mathrm{mL} / \mathrm{g})\end{array}$ & $\begin{array}{c}\text { Emulsifying } \\
\text { capacity }(\%)\end{array}$ & $\begin{array}{c}\text { Emulsifying } \\
\text { stability }(\%)\end{array}$ & $\begin{array}{c}\text { Foaming capacity } \\
(\%)\end{array}$ \\
\hline Raw & $4.23 \pm 0.39^{\mathrm{f}}$ & $4.52 \pm 1.58^{\mathrm{f}}$ & $17.90 \pm 0.26^{\mathrm{b}}$ & $4.90 \pm 0.42^{\mathrm{c}}$ & $19.02 \pm 1.87^{\mathrm{d}}$ & $13.93 \pm 0.98^{\mathrm{de}}$ & $0.75 \pm 0.96^{\mathrm{f}}$ \\
$\mathrm{SC60}$ & $5.84 \pm 0.33^{\mathrm{e}}$ & $18.84 \pm 0.89^{\mathrm{e}}$ & $19.50 \pm 0.95^{\mathrm{a}}$ & $5.45 \pm 0.41^{\mathrm{bc}}$ & $18.08 \pm 1.41^{\mathrm{d}}$ & $12.03 \pm 1.95^{\mathrm{e}}$ & $4.00 \pm 3.65^{\mathrm{f}}$ \\
$\mathrm{SC60H}$ & $12.16 \pm 0.33^{\mathrm{d}}$ & $56.17 \pm 2.20^{\mathrm{c}}$ & $8.30 \pm 0.48^{\mathrm{e}}$ & $7.65 \pm 0.76^{\mathrm{a}}$ & $53.26 \pm 1.82^{\mathrm{ab}}$ & $47.11 \pm 1.00^{\mathrm{ab}}$ & $318 \pm 12.44^{\mathrm{b}}$ \\
$\mathrm{SC} 120$ & $6.76 \pm 0.19^{\mathrm{e}}$ & $25.31 \pm 1.83^{\mathrm{d}}$ & $17.45 \pm 0.44^{\mathrm{bc}}$ & $5.44 \pm 0.44^{\mathrm{bc}}$ & $45.02 \pm 1.04^{\mathrm{c}}$ & $44.61 \pm 1.40^{\mathrm{b}}$ & $83.00 \pm 3.83^{\mathrm{d}}$ \\
$\mathrm{SC120H}$ & $13.82 \pm 0.40^{\mathrm{cd}}$ & $58.66 \pm 4.05^{\mathrm{c}}$ & $4.79 \pm 0.37^{\mathrm{f}}$ & $7.30 \pm 0.62^{\mathrm{a}}$ & $47.51 \pm 1.76^{\mathrm{bc}}$ & $44.02 \pm 1.74^{\mathrm{bc}}$ & $359.00 \pm 13.61^{\mathrm{a}}$ \\
$\mathrm{NB} 30$ & $6.52 \pm 0.47^{\mathrm{e}}$ & $24.94 \pm 2.05^{\mathrm{d}}$ & $14.75 \pm 0.42^{\mathrm{d}}$ & $4.90 \pm 0.53^{\mathrm{c}}$ & $51.70 \pm 1.80^{\mathrm{b}}$ & $16.75 \pm 1.64^{\mathrm{d}}$ & $8.00 \pm 1.63^{\mathrm{f}}$ \\
$\mathrm{NB} 30 \mathrm{H}$ & $20.42 \pm 1.45^{\mathrm{a}}$ & $73.06 \pm 1.69^{\mathrm{b}}$ & $3.82 \pm 0.21^{\mathrm{h}}$ & $6.25 \pm 0.53^{\mathrm{b}}$ & $56.15 \pm 4.84^{\mathrm{ab}}$ & $47.41 \pm 1.85^{\mathrm{ab}}$ & $182.50 \pm 5.97^{\mathrm{c}}$ \\
$\mathrm{NB} 60$ & $14.54 \pm 1.26^{\mathrm{c}}$ & $30.40 \pm 3.93^{\mathrm{d}}$ & $16.28 \pm 0.97^{\mathrm{c}}$ & $5.30 \pm 0.26^{\mathrm{bc}}$ & $53.82 \pm 1.71^{\mathrm{ab}}$ & $40.15 \pm 1.97^{\mathrm{c}}$ & $34.50 \pm 5.00^{\mathrm{e}}$ \\
$\mathrm{NB} 6 \mathrm{H}$ & $22.59 \pm 1.25^{\mathrm{a}}$ & $87.11 \pm 1.69^{\mathrm{a}}$ & $3.52 \pm 0.43^{\mathrm{h}}$ & $5.45 \pm 0.51^{\mathrm{bc}}$ & $50.18 \pm 1.00^{\mathrm{bc}}$ & $44.01 \pm 0.82^{\mathrm{bc}}$ & $293.75 \pm 26.59^{\mathrm{b}}$ \\
$\mathrm{A}$ & $13.68 \pm 1.03^{\mathrm{cd}}$ & $60.39 \pm 2.13^{\mathrm{c}}$ & $17.84 \pm 0.44^{\mathrm{b}}$ & $4.87 \pm 0.36^{\mathrm{c}}$ & $57.94 \pm 0.89^{\mathrm{a}}$ & $50.34 \pm 2.89^{\mathrm{a}}$ & $94.00 \pm 6.32^{\mathrm{d}}$ \\
$\mathrm{AH}$ & $16.85 \pm 1.25^{\mathrm{b}}$ & $86.14 \pm 2.88^{\mathrm{a}}$ & $4.10 \pm 0.50^{\mathrm{g}}$ & $6.05 \pm 0.42^{\mathrm{bc}}$ & $46.51 \pm 1.80^{\mathrm{c}}$ & $44.15 \pm 0.40^{\mathrm{bc}}$ & $303.00 \pm 8.87^{\mathrm{b}}$ \\
\hline
\end{tabular}

Values are reported in mean \pm standard deviation $(\mathrm{n}=2)$. Different alphabet superscript $\left({ }^{\mathrm{a}-\mathrm{g}}\right)$ indicates significant difference $(\mathrm{p}<0.05)$ between within the same column. 
non-hydrolysed EBN samples. For hydrolysed EBN, $\mathrm{NB} 60 \mathrm{H}(87.11 \%)$ and $\mathrm{AH}(86.14 \%)$ gave the highest solubility, followed by $\mathrm{NB} 30 \mathrm{H}(73.069 \%)$, and finally $\mathrm{SC} 120 \mathrm{H}(58.66 \%)$ and $\mathrm{SC} 60 \mathrm{H}(56.17 \%)(\mathrm{p}<0.05)$. The high solubility of hydrolysed EBN samples could be due to the reduction of the secondary structure of protein and the release of smaller, more hydrophilic and more solvated polypeptide units during protein hydrolysis (Adler-Nissen, 1986; Chobert et al., 1988). In addition, enzymatic protein hydrolysis converts some hydrophobic groups into hydrophilic ones by generating two end carbonyl and amino groups (Kristinsson and Rasco, 2000a). Therefore, the smaller peptides are expected to have more polar residues, increasing hydrophilicity through an increased ability to form hydrogen bonds with water (Sathivel et al., 2004). Nonetheless, the balance of hydrophilic and hydrophobic forces of peptides is another crucial influence on solubility increments (Gbogouri et al., 2004). However, excessive proteolysis can expose hydrophobic peptides which increase aggregation, causing a decrease in solubility. Besides, Paraman et al. (2007) observed that highly hydrophobic and sulfhydryl disulphide interactions contributed to protein insolubility, even with high $\mathrm{DH}$.

Furthermore, there was a very high positive correlation between DH and solubility of EBN ( $\mathrm{r}=$ 0.908). Similar finding has been reported for hydrolysates from shark protein (Diniz and Martin, 1997) (DH range: 43-68\%), yellow stripe trevally (Klompong et al., 2007) (DH range: 5 - 25\%), salmon by -products (Gbogouri et al., 2004)(DH range: 11.5 17.3\%) and silver catfish frame (Amiza et al., 2012) (DH range: $43-68 \%)$. However, DH has no effect on the solubility of protein hydrolysates of cobia (Amiza et al., 2012) (solubility range 85 - 86\%) (DH range: 53 - 96\%) and Pacific whiting (Pacheco-Aguilar et al., 2008) (solubility range almost 100\%) (DH range: 10 - 20\%).

Due to its high solubility, EBN hydrolysates can be considered as a good food ingredient or additive because it is easily dissolved. The high solubility of EBN hydrolysates, particularly $\mathrm{NB} 60 \mathrm{H}$ and $\mathrm{AH}$ facilitates potential application in a lot of food formulation by providing an attractive appearance and smooth mouthfeel to the products. Soluble EBN hydrolysates also can be fully utilized in nutraceutical and cosmetic products.

The solubility of $\mathrm{NB} 60 \mathrm{H}$ and $\mathrm{AH}$ obtained were similar to those reported for egg albumin (89.8\%) (Sathivel et al., 2004) and for egg-yolk protein hydrolysate (87.6\%) (Pokora et al., 2013). Nevertheless, the solubility of $\mathrm{NB} 60 \mathrm{H}$ and $\mathrm{AH}$ were higher than those of milk protein concentrate $(45.8 \%)$ and milk protein hydrolysate $(70.4-83.3 \%)$ (Banach et al., 2013) as well as egg-white protein hydrolysate (68.12\%) (Sun et al., 2013). This study shows that NB60H and AH samples are suitable to be used as a food ingredient due to their good solubility.

\subsubsection{Water holding capacity (WHC)}

WHC refers to the ability of the protein to imbibe and retain the water against gravitational forces within a protein matrix. Water molecules bind to several groups in proteins including charged groups, backbone peptide groups, the amide groups of Asn and $\mathrm{Gln}, \mathrm{OH}$ group of Ser, Try, Thr and nonpolar residues (Damodaran and Parkin, 2017). This means that WHC increases with increase in the number of charged residues in a protein. In general, limited proteolysis can unfold protein and expose hydrophilic side chains binding to water and thereby improve WHC. However, if excessive protein unfolding occurs during heat denaturation, this will result in protein aggregation causing a reduction in the availability of polar amino groups for hydrogen bonding with water, thus reduces water holding capacity of protein (Damodaran and Parkin, 2017).

WHC of lyophilized EBN varied with different treatments ranging from $4.10-19.50 \mathrm{~mL} / \mathrm{g}$ (Table 1). Taking into consideration significant difference between treatments, the WHC of EBN samples in decreasing order was given by SC60 > Raw, A, SC120, NB60 > $\mathrm{NB} 30>\mathrm{SC} 60 \mathrm{H}>\mathrm{SC} 120 \mathrm{H}>\mathrm{AH}>\mathrm{NB} 30 \mathrm{H}, \mathrm{NB} 60 \mathrm{H}$.

For the five EBN treatments that undergone heat treatment only, the highest WHC was given by SC60 (19.5\%), followed by Raw, A, SC120 and NB60 (16.28 $17.9 \%$ ) and finally NB30 (14.75\%). For Raw, A, SC120, NB60 treatments, there was no significant difference in WHC among these heat treatments. For similar heat treatment, WHC was greatly reduced for the Alcalase ${ }^{\circledR}$ hydrolysed EBN sample as compared to those of nonhydrolysed EBN. The highest WHC for hydrolysed EBN treatment was given by $\mathrm{SC} 60 \mathrm{H}(8.30 \mathrm{~mL} / \mathrm{g})$, followed by $\mathrm{SC} 120 \mathrm{H}(4.79 \mathrm{~mL} / \mathrm{g}), \mathrm{AH}(4.10 \mathrm{mg} / \mathrm{mL})$ and finally $\mathrm{NB} 30 \mathrm{H}$ and $\mathrm{NB} 60 \mathrm{H}(3.52-3.82 \mathrm{mg} / \mathrm{mL})$.

Furthermore, Pearson correlation shows a marked negative relationship $(r=0.794)$ between DH and WHC was observed in EBN samples. As stated previously, limited proteolysis will help to increase WHC, but excessive proteolysis will do otherwise. Thus, depending on the nature of protein and the extent of proteolysis, mixed trends were reported by previous studies. Similar trends were reported for shark hydrolysate (Diniz and Martin, 1997) (DH range 6.5 - 13.8\%). However, Amiza et al. (2013) reported that the WHC of silver catfish frame hydrolysate at DH $43 \%$ was significantly lower compared to those of DH 55\% and DH $68 \%$. However, 
there was no significant difference in the WHC between hydrolysate at $\mathrm{DH} 55 \%$ and $\mathrm{DH} 68 \%$. It was reported that WHC increased with increasing DH for grass carp skin hydrolysate (Wasswa et al., 2007) (DH range: 5.02 $14.9 \%$ ), but WHC was not affected by $\mathrm{DH}$ for eel hydrolysate (Baharuddin et al., 2016) (DH range: 36 $69 \%)$.

WHC of non-hydrolysed EBN samples obtained in this study was similar to that of egg-white protein hydrolysate $(17.28 \mathrm{~mL} / \mathrm{g})$, while hydrolysed EBN samples showed comparable WHC to egg-yolk protein hydrolysate $(5.12 \mathrm{~mL} / \mathrm{g})$ (Pokora et al., 2013), whey protein concentrate $(3.77 \mathrm{~mL} / \mathrm{g})$ and calcium caseinate $(6.11 \mathrm{~mL} / \mathrm{g})($ Carvalho-Silva et al., 2013). Nevertheless, WHC of EBN samples in this study was much higher than those reported for whey protein isolate and hydrolysate $(1.82 \mathrm{~mL} / \mathrm{g}$ and $2.63 \mathrm{~mL} / \mathrm{g}$, respectively) (Carvalho-Silva et al., 2013) and fish protein hydrolysates (Wasswa et al., 2007). It has been suggested that the WHC depends on the nature of the hydrolytic enzyme, preheating treatment and $\mathrm{pH}$ during hydrolysis (Panyam and Kilara, 1996), as well as the presence of different type of hydrophilic carbohydrates and varied protein structure (Seena and Sridhar, 2005).

\subsubsection{Oil holding capacity $(\mathrm{OHC})$}

OHC of EBN samples ranged from $4.87-7.65 \mathrm{mg} /$ $\mathrm{mL}$ (Table 1). Taking into consideration the significant difference between treatments, the OHC of EBN samples in decreasing order was given by $\mathrm{SC} 60 \mathrm{H}, \mathrm{SC} 120 \mathrm{H}>$ NB30H, AH, NB60H, NB60, SC120, SC60, A, Raw, NB30. SC60H and SC120H $(7.30-7.65 \mathrm{~mL} / \mathrm{g})$ treatments exhibited significantly higher $\mathrm{OHC}$ than other EBN samples. Pearson correlation results show that there was no correlation between the $\mathrm{OHC}$ and $\mathrm{DH}$ of EBN. A similar trend has been reported in cobia frame hydrolysate and shark hydrolysate (Diniz and Martin, 1997; Amiza et al., 2012). However, for grass carp skin hydrolysate and salmon byproducts hydrolysate, OHC was inversely proportionate to DH (Gbogouri et al., 2004; Wasswa et al., 2007).

In general, limited proteolysis can liberate some peptides from the native protein, which would enhance the flexibility of the peptides and thus result in improved fat absorption of proteins (Mahajan and Dua, 1998; Cho et al., 2008). However, extensive proteolysis and decrease in hydrophobic interactions could result in a decrease of OHC (Haque and Mozaffar, 1992).

The OHC of EBN obtained in this study was much higher than that of egg-white protein hydrolysate (3.42 $\mathrm{mL} / \mathrm{g}$ ) (Sun et al., 2013), grass carp skin hydrolysate (3.4 - $3.8 \mathrm{~mL} / \mathrm{g}$ ) (Wasswa et al., 2007), whey protein hydrolysate $(0.16-0.34 \mathrm{~mL} / \mathrm{g})$ (Sinha et al., 2007) and cobia frame hydrolysate $(2.4-2.8 \mathrm{~mL} / \mathrm{g}$ ) (Amiza et al., 2012). OHC is affected by many different factors, such as the type of protein, the type of enzyme used, the DH, the hydrolysis conditions and the oil used (Kristinsson and Rasco, 2000a). Besides, the difference in OHC may be due to the variation in the presence of non-polar side chains, which bind the hydrocarbon side chain of oil (Seena and Sridhar, 2005).

\subsubsection{Emulsifying capacity (EC) and emulsion stability (ES)}

Emulsifying capacity (EC) is generally used to measure the ability of the protein to form emulsions (Chalamaiah et al., 2010). Hydrolysates are surfaceactive materials and promote oil-in-water emulsion as they have both hydrophilic and hydrophobic groups (Gbogouri et al., 2004). It is generally accepted that limited hydrolysis improves the emulsification properties of proteins by exposing hydrophobic amino acid residue, which may interact with oil; while the hydrophilic residues interact with water (Damodaran and Parkin, 2017). A partially denatured state of proteins that retains the secondary structure but not the tertiary structure of the native protein (Panyam and Kilara, 1996). The smaller peptides often have reduced EC because small peptides are less efficient in unfolding and reorienting at the oil-water interface (Kristinsson and Rasco, 2000a). A peptide is required to have a minimum length of 20 residues to possess good emulsifying and interfacial properties (Lee et al., 1987).

EC of EBN samples ranged from 18.08 - 57.94\% (Table 1). A, NB60 and NB30H exhibited among the highest EC value (53.82 - 57.94\%), while Raw (19.02\%) and SC60 (18.08\%) gave the lowest EC values. Pearson correlation shows that EC of EBN samples was positively correlated with $\mathrm{DH}(\mathrm{r}=0.785)$. A similar trend was reported for egg yolk hydrolysate (DH range: 0 - 15\%) (Bao et al., 2017). However, for hydrolysates from sardinella by-product, yellow stripe trevally, grass carp skin and salmon byproduct, it was reported that EC was higher at lower DH (Gbogouri et al., 2004; Souissi et al., 2007; Klompong et al., 2007; Wasswa et al., 2007). Euston et al. (2001) also reported that EC for whey protein was affected by DH. Moderate DH (10 $27 \%$ ) gave higher EC compared to low DH (4 - 10\%) and high DH (27 - 35\%). EC of EBN samples obtained in this study was in a similar range with peanut protein isolate (57.28\%) (Kain et al., 2009) and acid whey protein concentrate $(25-82 \%)$ (Liao and Mangino, 1987).

ES of EBN samples ranged from 12.03 to $50.34 \%$. Table 1 shows that among the EBN samples, SC60, Raw 
and NB60 gave the lowest ES, and all other samples gave significantly higher FS than these three treatments. ES was also found to have a positive correlation with DH $(\mathrm{r}=0.719)$. Protein hydrolysis may have increased the occurrence of protein diffusion and orientation at the oilwater interface resulted in high emulsion stability (Kain et al., 2009). A similar trend was observed by Cho et al. (2008) for Hwangtae protein hydrolysate. This finding is in agreement with several previous studies which have reported that limited hydrolysis has good emulsion stability (Panyam and Kilara, 1996; Kristinsson and Rasco, 2000b); while the smaller peptides from extensive hydrolysis were detrimental to emulsifying properties (Klompong et al., 2007). ES of EBN samples obtained in this study was lower than that of peanut protein isolate (65.87\%) and hydrolysate (70.57\%) (Kain et al., 2009).

There are many different factors that may account for the difference observed between hydrolysates in both the ability to form and stabilize an emulsion. Peptide molecular characteristics such as hydrophobicity, amino acid composition (Panyam and Kilara, 1996); peptide chain length (Kristinsson and Rasco, 2000a) and DH (Cho et al., 2005) show the major impact. Meanwhile, environmental conditions such as $\mathrm{pH}$, ionic strength and temperature also have an effect on the emulsification properties (Damodaran and Parkin, 2017). The high emulsifying properties of $\mathrm{A}, \mathrm{NB} 30 \mathrm{H}$ and $\mathrm{SC} 60 \mathrm{H}$ samples indicate that EBN powder can be a good emulsifier.

\subsubsection{Foaming capacity (FC) and stability (FS)}

Foaming capacity (EC) is generally used to measure the ability of the protein to form foam a tenacious film at gas-liquid interfaces so that large quantities of air bubbles can be incorporated (Damodaran and Parkin, 2017). Limited enzymatic protein hydrolysis generally improves their foaming properties due to increased molecular flexibility and greater exposure of the hydrophobic groups. However, extensive proteolysis impairs foaming capacity because low molecular weight peptides cannot form a cohesive film at the interface (Damodaran and Parkin, 2017).

FC of lyophilized EBN varied with different treatments ranging from $0.75-359 \%$ (Table 1). Taking into consideration significant difference between treatments, the FC of EBN samples in decreasing order was given by $\mathrm{SC} 120 \mathrm{H}>\mathrm{SC} 60 \mathrm{H}, \mathrm{NB} 60 \mathrm{H}, \mathrm{AH}>\mathrm{NB} 30 \mathrm{H}$ $>\mathrm{SC} 120, \mathrm{~A}>\mathrm{NB} 60>\mathrm{NB} 30, \mathrm{SC} 60$, Raw. For the 5 EBN treatments that undergone heat treatment only, the highest FC was given by A (94\%) and SC120 (83\%), followed by NB60 (34.5\%) and finally NB30, SC60, Raw $(0.75-8 \%)$.
For similar heat treatment, FC values were greatly increased for Alcalase $\AA$-hydrolysed EBN samples as compared to those of non-hydrolysed EBN. The highest FC for hydrolysed EBN treatment was given by EC120H (359\%), followed by SC60H, NB60H and AH (293.75 $318 \%$ ) and finally $\mathrm{NB} 30 \mathrm{H}(182.5 \%)$. The $\mathrm{FC}$ of Alcalase ${ }^{\circledR}$-hydrolysed EBN samples was significantly higher than those of raw and non-hydrolysed EBN samples. This result is consistent with Adler-Nissen (1986) who reported an improvement in FC for enzymatically modified food protein. The hydrolysis of the protein produces a range of peptides which possess the altered hydrophobicity, charge balance and conformation, compared to the native molecule. Protein hydrolysate with reduced molecular weight is flexible in forming a stable interfacial layer and increasing the rate of diffusion to the interface, leading to improved foaming properties (Adler-Nissen, 1986). However, a contradictory trend was reported for hydrolysates from cobia, shark and yellow stripe trevally whereby FC decreased with increasing DH (Diniz and Martin, 1997; Klompong et al., 2007; Amiza et al., 2012).

The low FC given by raw and non-hydrolysed EBN could be due to the fact that the larger peptides and nonhydrolysed proteins exert an inhibitory effect on the foaming properties of the smaller peptides either by hydrophobic interaction or by steric hindrance at the interface (Panyam and Kilara, 1996).

FC of hydrolysed EBN obtained in this study was much higher than those reported for sodium caseinate hydrolysate (150\%) (Giardina et al., 2004), but was lower than commercial whey protein concentrate $(500 \%)$ and whey protein hydrolysate $(560 \%$ at $\mathrm{DH} 2.8 \%)$ (Lieske and Konrad, 1996).

Foaming stability (FS) of lyophilized EBN samples decreased with time (Table 2). The significant difference in FS $(p<0.05)$ were more noticeable with increased time. Among the samples, A and NB30 treatments produced the most stable foam, retaining $96.39 \%$ and $93.54 \%$ of foam after $60 \mathrm{~min}$, respectively. The presence of large protein components and partially hydrolysed protein, which function to stabilize the foam, contributed to the observed foam stability (Claver and Zhou, 2005). Meanwhile, although hydrolysis of the EBN samples increased the $\mathrm{FC}$ of $\mathrm{NB} 30 \mathrm{H}$ and $\mathrm{NB} 60 \mathrm{H}$, the stability of foam formed was very poor. Small peptides are able to incorporate more air into the dispersions than larger peptides, but they do not have enough strength to give a stable foam (Kristinsson and Rasco, 2000a).

FS of EBN was comparable to sodium caseinate (95.15\%) (Giardina et al., 2004), but was higher than commercial whey protein concentrate $(38 \%)$ and whey 
Table 2. Foaming stability of lyophilized EBN as affected by heat treatments and protein hydrolysis

\begin{tabular}{cccccc}
\hline \multirow{2}{*}{ Sample } & \multicolumn{5}{c}{ Foaming stability (\%) } \\
\cline { 2 - 6 } & $5 \mathrm{mins}$ & $10 \mathrm{mins}$ & $20 \mathrm{mins}$ & $40 \mathrm{mins}$ & $60 \mathrm{mins}$ \\
\hline $\mathrm{SC60H}$ & $100.00 \pm 0.00^{\mathrm{Aa}}$ & $100.00 \pm 0.00^{\mathrm{Aa}}$ & $98.09 \pm 1.29^{\mathrm{Aa}}$ & $91.76 \pm 0.35^{\mathrm{Bab}}$ & $79.07 \pm 2.92^{\mathrm{Cc}}$ \\
$\mathrm{SC} 120$ & $96.76 \pm 1.44^{\mathrm{Aab}}$ & $94.08 \pm 3.66^{\mathrm{Aa}}$ & $90.82 \pm 3.56^{\mathrm{Aa}}$ & $88.11 \pm 4.24^{\mathrm{Ab}}$ & $84.29 \pm 3.37^{\mathrm{Abc}}$ \\
$\mathrm{SC} 120 \mathrm{H}$ & $97.78 \pm 0.71^{\mathrm{Aa}}$ & $97.12 \pm 0.42^{\mathrm{Aa}}$ & $95.14 \pm 0.44^{\mathrm{Aa}}$ & $94.69 \pm 0.20^{\mathrm{Aab}}$ & $87.58 \pm 1.72^{\mathrm{Bb}}$ \\
$\mathrm{NB} 30$ & $99.06 \pm 1.34^{\mathrm{ABa}}$ & $98.15 \pm 0.05^{\mathrm{Aba}}$ & $95.39 \pm 1.19^{\mathrm{Ba}}$ & $94.45 \pm 0.15^{\mathrm{Bab}}$ & $93.54 \pm 1.14^{\mathrm{Bbc}}$ \\
$\mathrm{NB} 30 \mathrm{H}$ & $92.80 \pm 6.20^{\mathrm{Ab}}$ & $85.99 \pm 7.86^{\mathrm{Ab}}$ & $77.75 \pm 11.56^{\mathrm{Ab}}$ & $71.37 \pm 6.64^{\mathrm{Ac}}$ & $63.52 \pm 5.79^{\mathrm{Ae}}$ \\
$\mathrm{NB} 60$ & $98.44 \pm 2.21^{\mathrm{Aa}}$ & $95.41 \pm 2.34^{\mathrm{Aba}}$ & $90.91 \pm 0.39^{\mathrm{Ba}}$ & $89.44 \pm 1.69^{\mathrm{Bbc}}$ & $83.37 \pm 1.44^{\mathrm{Cbc}}$ \\
$\mathrm{NB} 60 \mathrm{H}$ & $100.00 \pm 0.00^{\mathrm{Aa}}$ & $99.45 \pm 0.78^{\mathrm{Aa}}$ & $97.23 \pm 0.78^{\mathrm{Aa}}$ & $91.11 \pm 0.00^{\mathrm{Bab}}$ & $58.89 \pm 3.14^{\mathrm{Ce}}$ \\
$\mathrm{A}$ & $97.37 \pm 2.31^{\mathrm{Aab}}$ & $97.37 \pm 2.31^{\mathrm{Aa}}$ & $97.37 \pm 2.31^{\mathrm{Aa}}$ & $96.39 \pm 0.9^{\mathrm{Aa}}$ & $96.39 \pm 0.91^{\mathrm{Aa}}$ \\
$\mathrm{AH}$ & $100.00 \pm 0.00^{\mathrm{Aa}}$ & $99.56 \pm 0.62^{\mathrm{Aa}}$ & $98.25 \pm 2.48^{\mathrm{Aa}}$ & $92.70 \pm 4.56^{\mathrm{Aab}}$ & $79.06 \pm 3.57^{\mathrm{Bd}}$ \\
\hline
\end{tabular}

Values are reported in mean \pm standard deviation $(n=2)$. Different alphabet superscripts $\left({ }^{\mathrm{a}-\mathrm{e}}\right)$ indicate significant difference $(p<0.05)$ within the same column; capital superscripts $\left({ }^{A-C}\right)$ indicate significant difference within the same row when analysed using one-way ANOVA with Tukey's multiple comparison test.

protein hydrolysate (65\%) (Lieske and Konrad, 1996). In general, foaming properties depends on the duration and degree of hydrolysis (Klompong et al., 2007). Foam stability mainly depends on the extent of protein-protein interactions within the matrix of the films surrounding the air bubbles and also the flexibility of protein or peptide structure (Klompong et al., 2007). Nevertheless, the good FC and excellent FS of A sample suggested that autoclaving is the most efficient heat treatment in producing EBN with desirable foaming properties.

\subsubsection{Colour}

Table 3 shows the colour profiles of lyophilized EBN powder prepared with different processing treatments. Pearson analysis shows that there was no correlation between DH and colour parameters ( $\mathrm{L}^{*}, \mathrm{a}^{*}$ and $\left.b^{*}\right)$. SC60H gave higher lightness $\left(\mathrm{L}^{*}\right)$ value than Raw, SC60, SC120H, NB30, and A. However, L* values of $\mathrm{SC} 120, \mathrm{NB} 30 \mathrm{H}, \mathrm{NB} 60, \mathrm{NB} 60 \mathrm{H}$ and $\mathrm{AH}$ were not significantly different with other samples. This indicates that $\mathrm{L}^{*}$ values of EBN were not affected by heat and protein hydrolysis treatments. $\mathrm{NB} 60 \mathrm{H}$ and $\mathrm{SC} 120 \mathrm{H}$ gave significantly higher green $\left(\mathrm{a}^{*}\right)$ values than those of Raw, A and AH. However, the $\mathrm{a}^{*}$ values of $\mathrm{SC} 60 \mathrm{H}$ was not significantly different with those of $\mathrm{NB} 60 \mathrm{H}, \mathrm{SC} 120 \mathrm{H}$, Raw, A and AH. This indicates that $a^{*}$ values of EBN were not affected by heat and protein hydrolysis treatments.

The highest yellowness $\left(b^{*}\right)$ values were given by $\mathrm{AH}$ and $\mathrm{NB} 60 \mathrm{H}$. While other treatments were not significantly different from each other. Differences in colour between EBN samples could also be attributed by differences between batches of EBN purchased from the supplier. The difference in the type of food and mineral constituents of the food the swiftlets consumed may cause variations in the colour intensity. Furthermore, Paydar et al. (2013) suggested that nitrite content and
EBN's colour was related, as EBN contained higher nitrite level usually has a darker colour. Meanwhile, EBN harvesting season may also contribute to the variation, as during rainy season, there are more insects as swiftlets' food (Norhayati et al., 2010).

\subsubsection{Viscosity}

Table 4 shows the viscosity of lyophilized EBN powder prepared with different processing treatments. As expected, the viscosity of EBN was concentration dependent. At low sample concentration (1\% and 3\%), both hydrolysed and non-hydrolysed samples gave low viscosity.

One-way ANOVA results show a significant difference $(p<0.05)$ in viscosity among EBN samples is noticeable with increased sample concentration. At high concentration, particularly $7 \%$ and $10 \%$, viscosity of EBN was negatively related to DH with high correlation $(r=0.772)$. The viscosity of Alcalase ${ }^{\circledR}$-hydrolysed EBN samples was significantly lower than those of nonhydrolysed EBN samples. Meanwhile, suspensions of $\mathrm{NB} 30 \mathrm{H}, \mathrm{NB} 60 \mathrm{H}, \mathrm{A}$ and $\mathrm{AH}$ were present as fluid even at the highest powder concentration $(10 \%)$. Only a slight increase in viscosity with increased concentration was observed in samples of high DH (13.68 - 22.59\%). These results are in agreement with Diniz and Martin (1997) who reported that proteolytic cleavage in the hydrolysis process reduces the viscosity of the protein hydrolysate. Therefore, an increase in DH could lead to reduction in viscosity (Diniz and Martin, 1997).

However, a great increase in viscosity with increased sample concentration was noticeable for the SC60 and raw samples with low DH (4.23 - 5.84\%), particularly at a higher concentration (10\%). The low DH could be explained by the fact that non-hydrolysed samples contain an insoluble fraction that contributes 
Table 3. Colour profiles of lyophilized EBN samples as affected by heat treatments and protein hydrolysis

\begin{tabular}{ccccc}
\hline \multirow{2}{*}{ Sample } & DH $(\%)$ & \multicolumn{3}{c}{ Hunter colour parameters } \\
\cline { 3 - 5 } & & $\mathrm{L}^{*}$ & $\mathrm{a}^{*}$ & $\mathrm{~b}^{*}$ \\
\hline Raw & 4.23 & $85.96 \pm 2.07^{\mathrm{b}}$ & $-4.67 \pm 0.19^{\mathrm{b}}$ & $13.09 \pm 0.30^{\mathrm{b}}$ \\
$\mathrm{SC60}$ & 5.84 & $86.92 \pm 0.46^{\mathrm{b}}$ & $-4.71 \pm 0.17^{\mathrm{bc}}$ & $12.12 \pm 0.22^{\mathrm{bc}}$ \\
$\mathrm{SC} 60 \mathrm{H}$ & 12.16 & $94.29 \pm 0.43^{\mathrm{a}}$ & $-4.95 \pm 0.09^{\mathrm{ab}}$ & $11.36 \pm 0.30^{\mathrm{c}}$ \\
$\mathrm{SC} 120$ & 6.76 & $89.79 \pm 1.45^{\mathrm{ab}}$ & $-4.90 \pm 0.04^{\mathrm{bc}}$ & $12.54 \pm 0.53^{\mathrm{bc}}$ \\
$\mathrm{SC} 120 \mathrm{H}$ & 13.82 & $87.01 \pm 2.34^{\mathrm{b}}$ & $-5.04 \pm 0.16^{\mathrm{a}}$ & $11.94 \pm 0.36^{\mathrm{c}}$ \\
$\mathrm{NB} 30$ & 6.52 & $89.34 \pm 0.82^{\mathrm{b}}$ & $-4.63 \pm 0.05^{\mathrm{bc}}$ & $12.37 \pm 0.56^{\mathrm{bc}}$ \\
$\mathrm{NB} 30 \mathrm{H}$ & 20.42 & $91.07 \pm 0.27^{\mathrm{ab}}$ & $-4.86 \pm 0.02^{\mathrm{bc}}$ & $12.83 \pm 0.43^{\mathrm{bc}}$ \\
$\mathrm{NB} 60$ & 14.54 & $91.63 \pm 3.05^{\mathrm{ab}}$ & $-4.89 \pm 0.09^{\mathrm{bc}}$ & $12.21 \pm 0.37^{\mathrm{bc}}$ \\
$\mathrm{NB} 6 \mathrm{H}$ & 22.59 & $92.00 \pm 1.55^{\mathrm{ab}}$ & $-4.73 \pm 0.15^{\mathrm{a}}$ & $14.38 \pm 0.42^{\mathrm{a}}$ \\
$\mathrm{A}$ & 13.68 & $89.17 \pm 0.91^{\mathrm{b}}$ & $-4.51 \pm 0.45^{\mathrm{b}}$ & $13.23 \pm 0.39^{\mathrm{b}}$ \\
$\mathrm{AH}$ & 16.85 & $92.88 \pm 2.40^{\mathrm{ab}}$ & $-4.92 \pm 0.12^{\mathrm{b}}$ & $14.87 \pm 0.22$ \\
\hline
\end{tabular}

$L^{*}$ : measure of lightness; $a^{*}$ : measure from green $(-a)$ to red $(+a) ; b^{*}$ : measure from blue $(-b)$ to yellow $(+b)$. Values are reported in mean \pm standard deviation $(n=2)$. Different alphabet superscripts $\left({ }^{\mathrm{a}-\mathrm{c}}\right)$ indicate significant difference $(\mathrm{p}<0.05)$ within the same column when analysed using one-way ANOVA with Tukey’s multiple comparison test.

Table 4. Viscosity of lyophilized EBN samples (in mPa.s) at different concentrations affected by different heat treatments and protein hydrolysis

\begin{tabular}{|c|c|c|c|c|c|c|}
\hline \multirow{2}{*}{ Sample } & \multirow{2}{*}{$\mathrm{DH}(\%)$} & \multicolumn{5}{|c|}{ Sample concentration $(\%, \mathrm{w} / \mathrm{v})$} \\
\hline & & $1 \%$ & $3 \%$ & $5 \%$ & $7 \%$ & $10 \%$ \\
\hline Raw & 4.23 & $63.33 \pm 15.3^{\mathrm{Ab}}$ & $83.33 \pm 5.7^{\mathrm{Bbc}}$ & $143.33 \pm 25.2^{\mathrm{Ce}}$ & $786.67 \pm 11.5^{\mathrm{Dd}}$ & $5666.67 \pm 23.1^{\mathrm{Db}}$ \\
\hline SC60 & 5.84 & $53.33 \pm 23.1^{\mathrm{Ab}}$ & $116.67 \pm 15.3^{\mathrm{Bb}}$ & $250.00 \pm 17.3^{\mathrm{Ccd}}$ & $1173.33 \pm 30.6^{\mathrm{Da}}$ & $7526.67 \pm 75.7^{\mathrm{Da}}$ \\
\hline $\mathrm{SC} 60 \mathrm{H}$ & 12.16 & $106.67 \pm 30.6^{\mathrm{Aab}}$ & $206.67 \pm 30.6^{\mathrm{Ba}}$ & $453.33 \pm 4.2^{\mathrm{Ca}}$ & $1086.67 \pm 11.5^{\mathrm{Db}}$ & $2486.67 \pm 110.2^{\text {Def }}$ \\
\hline $\mathrm{SC} 120$ & 6.76 & $26.67 \pm 11.5^{\mathrm{Ab}}$ & $53.33 \pm 11.5^{\mathrm{Bc}}$ & $206.67 \pm 11.5^{\mathrm{Cd}}$ & $580.00 \pm 20.0^{\mathrm{Df}}$ & $2563.33 \pm 90.7^{\mathrm{De}}$ \\
\hline $\mathrm{SC} 120 \mathrm{H}$ & 13.82 & $26.67 \pm 11.5^{\mathrm{Ab}}$ & $140.00 \pm 20.0^{\mathrm{Bab}}$ & $346.67 \pm 11.5^{\mathrm{Cb}}$ & $803.33 \pm 20.8^{\mathrm{Dd}}$ & $2313.33 \pm 11.5^{\mathrm{Ef}}$ \\
\hline NB30 & 6.52 & $70.00 \pm 10.00^{\mathrm{Ab}}$ & $116.00 \pm 3.5^{\mathrm{Bb}}$ & $458.33 \pm 14.4^{\mathrm{Ca}}$ & $720.00 \pm 34.6^{\mathrm{De}}$ & $3300.00 \pm 52.9^{\mathrm{Dc}}$ \\
\hline NB30H & 20.42 & $63.33 \pm 15.3^{\mathrm{Ab}}$ & $128.50 \pm 25.2^{\mathrm{Bbc}}$ & $210.00 \pm 20.0^{\mathrm{Bd}}$ & $253.33 \pm 11.5^{\mathrm{Ch}}$ & $1083.33 \pm 28.9^{\mathrm{Cg}}$ \\
\hline NB60 & 14.54 & $66.67 \pm 11.5^{\mathrm{Ab}}$ & $200.00 \pm 20.0^{\mathrm{Ba}}$ & $246.67 \pm 23.1^{\mathrm{Ccd}}$ & $873.33 \pm 30.6^{\mathrm{Cc}}$ & $3046.67 \pm 70.2^{\mathrm{Dd}}$ \\
\hline $\mathrm{NB} 60 \mathrm{H}$ & 22.59 & $136.67 \pm 15.3^{\mathrm{Aa}}$ & $186.67 \pm 30.6^{\mathrm{Ba}}$ & $266.67 \pm 30.6^{\mathrm{Bc}}$ & $323.33 \pm 25.2^{\mathrm{Cg}}$ & $706.67 \pm 11.5^{\mathrm{Ch}}$ \\
\hline A & 13.68 & $26.67 \pm 11.5^{\mathrm{Ab}}$ & $66.67 \pm 11.5^{\mathrm{Bbc}}$ & $113.33 \pm 11.5^{\mathrm{Ce}}$ & $326.67 \pm 11.5^{\mathrm{Dg}}$ & $540.00 \pm 20.0^{\mathrm{Dh}}$ \\
\hline $\mathrm{AH}$ & 16.85 & $53.33 \pm 11.5^{\mathrm{Ab}}$ & $86.67 \pm 11.5^{\mathrm{Bbc}}$ & $153.33 \pm 30.6^{\mathrm{Ce}}$ & $206.67 \pm 23.1^{\mathrm{Dh}}$ & $293.33 \pm 11.5^{\mathrm{Di}}$ \\
\hline
\end{tabular}

Values are reported in mean \pm standard deviation) $(n=2)$. Different alphabet superscripts $\left({ }^{\text {a-e }}\right)$ indicates significant difference $(p<0.05)$ within the same column; different capital superscripts $\left({ }^{A-D}\right)$ indicates significant different within the same row when analysed using one-way ANOVA with Tukey's multiple comparison.

significantly to the swelling ability (Sze-Tao and Sathe, The low viscosity of high DH EBN samples, particularly 2000), which is a contributing factor to the viscosity of $\mathrm{NB} 30 \mathrm{H}, \mathrm{NB} 60 \mathrm{H}, \mathrm{A}$ and $\mathrm{AH}$, even at high concentration protein solutions. Furthermore, protein-protein could find application in the development of high protein interactions in dispersions of the original protein are liquid food without suffering the adverse consequences stronger than the peptides-water interactions in the of high viscosity (Diniz and Martin, 1997; Sze-Tao and hydrolysed substrates (Diniz and Martin, 1997), thus Sathe, 2000).

resulting in higher viscosity.

The viscosity of both Alcalase ${ }^{\circledR}$-hydrolysed EBN samples (293 - $2487 \mathrm{mPa} . \mathrm{s})$ and non-hydrolysed EBN samples (540 - $7527 \mathrm{mPa} . \mathrm{s}$ ) were very high. The range of viscosity given by EBN in this study was much higher than those reported for other proteins such as calcium caseinate (181.5 mPa.s), whey protein isolate (140.7 $\mathrm{mPa} . \mathrm{s})$ and soy protein hydrolysate $(250 \mathrm{mPa} . \mathrm{s}$ at $10 \%)$ (Tsumura et al., 2005). These results showed that EBN has excellent viscosity as compared to other proteins and thus, possesses a good potential as a thickening agent.

\subsection{SDS-PAGE}

Figure 1 shows the SDS-PAGE of control EBN (without any treatment), SC60 and SC60H samples. The figure shows that control EBN has two distinct bands at $139 \mathrm{kDa}$ and $126 \mathrm{kDa}$ and a faded band at the bottom of the gel. Meanwhile, SC60 sample shows the dominant band at the top of the gel, suggesting that most proteins cannot get through the SDS-PAGE gel matrix. However, there was also a presence of smearing band between the top of the gel until before $50 \mathrm{kDa}$ and a band at the 
bottom of the gel, similar to that of SC60H. Wong et al. (2018) also reported a similar finding whereby the EBN protein cannot get through the SDS-PAGE gel matrix as well as streaking around the protein band. This may be due to the unusual richness of high-density glycoprotein in EBN (Marcone, 2005). Meanwhile, SC60H protein band shows that almost all protein present in smaller peptides with molecular weight of less than $20 \mathrm{kDa}$.

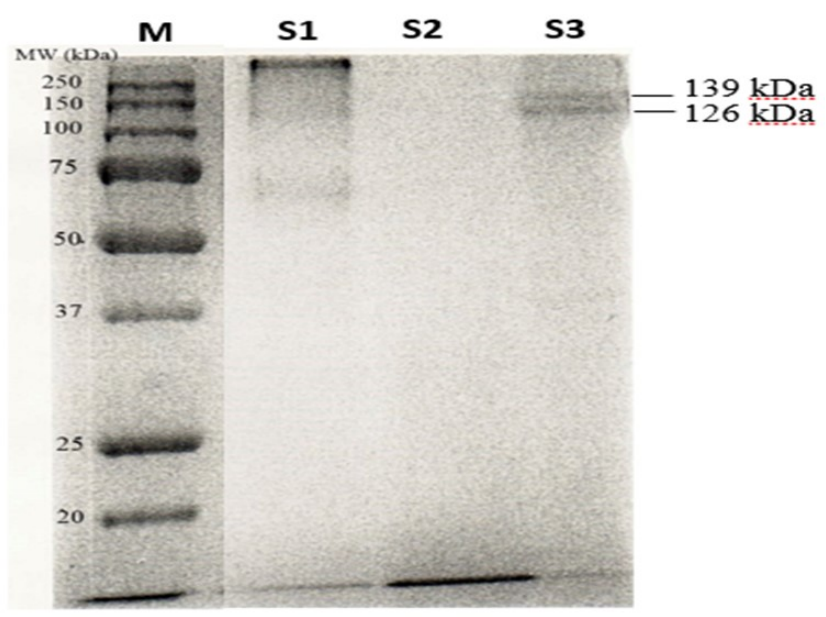

Figure 1.SDS-PAGE of protein from edible bird's nest samples. Lane M: molecular weight marker, Lane S1: SC60, Lane S2: SC60H, Lane S3: control EBN (without any treatment).

\section{Conclusion}

This study showed that heat treatment and protein enzymatic hydrolysis greatly influenced the degree of hydrolysis (DH) and physicochemical properties of EBN. It was found that heat treated EBN samples gave lower DH compared to those undergone combined heat treatment and enzymatic protein hydrolysis. It was found that there was a positive correlation between $\mathrm{DH}$ and solubility, emulsifying capacity and emulsifying stability of EBN samples. However, a negative correlation was found between DH and water holding capacity and viscosity of EBN samples. Furthermore, there was no correlation between DH and oil holding capacity and colour profiles. Thus, this study shows that heat treatment and enzymatic hydrolysis of EBN can be tailored to achieve a certain degree of hydrolysis and physicochemical properties.

\section{Conflict of Interest}

The authors declare that there is no conflict of interest regarding the publication of this article.

\section{Acknowledgements}

This research did not receive any specific grant from funding agencies in the public, commercial, or not-for- profit sectors.

\section{References}

Adler-Nissen, J. (1986). Enzymatic hydrolysis of food protein., p. 427. New York: Elsevier Applied Science Publisher.

Amiza, M.A., Kong, Y.L. and Faazaz, A.L. (2012). Effects of degree of hydrolysis on physicochemical properties of Cobia (Rachycentron canadum) frame hydrolysate. International Food Research Journal, 19(1), 199-206.

Amiza, M.A., Oon, X.X. and Norizah, M.S. (2019). Optimization of enzymatic hydrolysis conditions on the degree of hydrolysis of edible bird's nest using Alcalase ${ }^{\circledR}$ and nutritional composition of the hydrolysate. Food Research, 3(5), 570 - 580. https:// doi.org/10.26656/fr.2017.3(5).120

Amiza, M.A., Ow, Y.W. and Faazaz, A.L. (2013). Physicochemical properties of silver catfish (Pangasius sp.) frame hydrolysate. International Food Research Journal, 20(3), 1255-1262.

Amiza M.A., Sai J.Y. and Sarbon, N.M. (2014). Optimization of enzymatic hydrolysis conditions on angiotensin converting enzyme (ACE) inhibitory activity from edible bird's nest. Proceedings of International Conference on Food Innovation 2014 (INNOVA2014). 27-29 August 2014. Penang, Malaysia: Universiti Sains Malaysia

AOAC. (2000). Methods of Analysis: Association of Official Analytical Chemists. 15th ed. Washington, DC: AOAC.

Baharuddin, N.A., Halim, N.A.A and Sarbon, N.M. (2016). Effect of degree of hydrolysis (DH) on the functional properties and angiotensin I-converting enzyme (ACE) inhibitory activity of eel (Monopterus sp.) protein hydrolysate. International Food Research Journal, 23(4), 1424-1431.

Banach, J.C., Lin, Z. and Lamsal, B.P. (2013). Enzymatic modification of milk protein concentrate and characterization of resulting functional properties. LWT - Food Science and Technology, 54 (2), 397-403. https://doi.org/10.1016/ j.lwt.2013.06.023

Bao, Z.-J., Zhao, Y., Wang, X.-Y. and Chi, Y-J. (2017). Effects of degree of hydrolysis (DH) on the functional properties of egg yolk hydrolysate with Alcalase ${ }^{\circledR}$. Journal of Food Science and Technology, 54(3), 669-678. https://doi.org/10.1007/ s13197-017-2504-0

Bhaskar, N. and Mahendrakar, N.S. (2008). Protein hydrolysate from visceral waste proteins of Catla (Catla catla): optimization of hydrolysis conditions for a commercial neutral protease. Bioresource 
Technology, 99(10), 4105-4111. https:// doi.org/10.1016/j.biortech.2007.09.006

Carvalho-Silva, L.B., Vissotto, F.Z. and Amaya-Farfan, J. (2013). Physico-chemical properties of milk whey protein agglomerates for use in oral nutritional therapy. Food and Nutrition Sciences, 4, 69-78. https://doi.org/10.4236/fns.2013.49A2010

Chalamaiah, M., Dinesh Kumar, B., Hemalatha, R. and Jyothirmayi, T. (2012). Fish protein hydrolysates: Proximate composition, amino acid composition, antioxidant activities and applications: A review. Food Chemistry, 135, 3020-3038. https:// doi.org/10.1016/j.foodchem.2012.06.100

Cho, S.S., Lee, H.K., Han, C.W., Seong, E.S., Yu, C.Y., Kim, M.J., Kim, N.Y., Kang, W.S., Ko, S.H., Son, E.H., Choung, M.G. and Lim, J.D. (2008). Physicochemical properties of isolated peptides from Hwangtae (yellowish dried pollack) protein hydrolysate. Journal of Food Science and Nutrition, 13, 204-211. https://doi.org/10.3746/ jfn.2008.13.3.204

Chobert, J.M., Bertrand, H.C. and Nicolas, M.G. (1988). Solubility and emulsifying properties of caseins and whey proteins modified enzymatically by trypsin. Journal of Agricultural and Food Chemistry, 36, 883 -892. https://doi.org/10.1021/jf00083a002

Claver, I.P. and Zhou, H. (2005). Enzymatic hydrolysis of defatted wheat germ by proteases and the effect on the functional properties of resulting protein hydrolysates. Journal of Food Biochemistry, 29(1), 13-26. https://doi.org/10.1111/j.17454514.2005.00004.x

Damodaran, S. and Parkin, K.L. (2017). Fennema's Food Chemistry. $7^{\text {th }}$ ed. New York: CRC Press.

Diniz, F.M. and Martin, A.M. (1997). Effects of the extent of enzymatic hydrolysis on the functional properties of shark protein hydrolysate. LWT - Food Science and Technology, 30(3), 266-272. https:// doi.org/10.1006/fstl.1996.0184

Euston, S., Finnigan, S.R. and Hirst, R.L. (2001). HeatInduced Destabilization of Oil-in-Water Emulsions Formed from Hydrolysed Whey Protein. Journal of Agricultural and Food Chemistry, 49(11), 5576-83. https://doi.org/10.1021/jf0102620

Gbogouri, G.A., Linder, M., Fanni, J. and Parmentier, M. (2004). Influence of hydrolysis degree on the functional properties of salmon by-products hydrolysate. Journal of Food Chemistry and Toxicology, 69, 615-622. https://doi.org/10.1111/ j.1365-2621.2004.tb09909.x

Giardina, C., Pelizzola, V., Avalli, A., Iametti, S. and Cattaneo, T.M.P. (2004). Functional properties of milk protein hydrolysates obtained by controlled enzymatic hydrolysis. Milchwissenschaft, 59, 476479.

Gisslen, W. (2011). Professional cooking. $7^{\text {th }}$ ed. USA: John Wiley and Sons.

Haque, Z.U. and Mozaffar, Z. (1992). Casein hydrolysate. II. Functional properties of peptides. Food Hydrocolloids, 5(6), 559-571. https:// doi.org/10.1016/S0268-005X(09)80125-2

Hoyle, N.T. and Merritt, J.H. (1994). Quality of fish protein hydrolysates from herring (Clupea harengus). Journal of Food Science, 59(1), 76-79. https://doi.org/10.1111/j.1365-2621.1994.tb06901.x

Kain, R.J., Chen, Z.X., Sonda, T.S. and Abu-Kpawoh, J.C. (2009). Study on the effects of enzymatic hydrolysis on the physical, functional and chemical properties of peanut protein isolates extracted from defatted heat pressed peanut meal flour (Arachis hypogaea L.). Pakistan Journal of Nutrition, 8(6), 818-825. https://doi.org/10.3923/pjn.2009.818.825

Klompong, V. Benjakul, S., Kantachote, D. and Shahidi, F. (2007). Antioxidative activity and functional properties of protein hydrolysate of yellow stripe trevally (Selaroides leptolepis) as influenced by the degree of hydrolysis and enzyme type. Food Chemistry, 102(4), 120-131. https://doi.org/10.1016/ j.foodchem.2006.07.016

Kong, Y.C., Keung, W.M., Yip, T.T., Ko, K.M., Tsao, S.W.T. and $\mathrm{Ng}$, M.H. (1987). Evidence that epidermal growth factor is present in swiftlet's (Collocalia) nest. Comparative Biochemistry and Physiology Part B: Comparative Biochemistry, 87 (2), 221-226. https://doi.org/10.1016/0305-0491(87) 90133-7

Kristinsson, H.G. and Rasco, B.A. (2000a). Fish protein hydrolysates: production, biochemical and functional properties. Critical Review of Food Science and Nutrition, 40(1), 43-81. https:// doi.org/10.1080/10408690091189266

Kristinsson, H.G. and Rasco, B.A. (2000b). Biochemical and functional properties of Atlantic salmon (Salmo salar) muscle proteins hydrolysed with various alkaline proteases. Journal of Agricultural and Food Chemistry, 48(3), 657-666. https://doi.org/10.1021/ jf990447v

Lee S.W., Shimizu, M., Kaminogawa, S. and Yamauchi, K. (1987). Emulsifying properties of a mixture of peptides from the enzymatic hydrolysates of $\beta$ casein. Agricultural and Biological Chemistry, 5(6), 1535-1540. https:// doi.org/10.1080/00021369.1987.10868259

Liao, S.Y. and Mangino, M.E. (1987). Characterization 
the composition, physicochemical and functional properties of acid whey protein concentrates. Journal of Food Science, 52(4), 1033-1037. https:// doi.org/10.1111/j.1365-2621.1987.tb14269.x

Lieske, B. and Konrad, G. (1996). Physicochemical and functional properties of whey protein as affected by limited papain proteolysis and selective ultrafiltration. International Dairy Journal, 6(1), 1331. https://doi.org/10.1016/0958-6946(94)00049-2

Lim, C.K. and Earl of Cranbrook. (2002). Swiftlets of Borneo: builders of edible nests., p. 171. Borneo: Natural History Publications.

Ma, F. and Liu, D. (2012). Sketch of the edible bird's nest and its important bioactivities. Food Research International, 48(2), 559-567. https:// doi.org/10.1016/j.foodres.2012.06.001

Mahajan, A. and Dua, S. (1998). Improvement of functional properties of rapeseed (Brassica compestris var toria) meal by reducing antinutritional factors employing enzymatic modification. Food Hydrocolloids, 12(3), 349-355. https://doi.org/10.1016/S0268-005X(98)00030-7

Marcone, M.F. (2005). Characterization of the edible bird's nest the "Caviar of the East". Food Research International, 38(10), 1125-1134. https:// doi.org/10.1016/j.foodres.2005.02.008

Mohamad Shukri, N.N.H., Mohd Nawi, N., Abdullah, A.M. and Man, N. (2018). Consumer's Perception on the Quality of Controversial Contents in Edible Bird's Nest Products. Pertanika Journal of Scholarly Research Reviews, 4(1), 1-9.

Morr, V., German, B., Kinsella, J.E., Regenstein, J.M., Van Buren, J.P. and Kilara, A. (1985). A collaborative study to develop a standardized food protein solubility procedure. Journal of Food Science, 50(6), 1715-1718. https://doi.org/10.1111/ j.1365-2621.1985.tb10572.x

Murano, P.S. (2003). Understanding Food Science and Technology. Belmont, CA: Thomson/Wadsworth.

Neto, V.Q., Narain N., Silva J.B. and Bora P.S. (2001). Functional properties of raw and heat processed cashew nut (Anarcarduim occidentale L.) kernel protein isolates. Nahrung/Food, 45, 258-262. https:// doi.org/10.1002/1521-3803(20010801) 45:4<258::AID-FOOD258>3.0.CO;2-3

Norhayati, M.K., Azman, O. and Wan Nazaimoon, W.M. (2010). Preliminary study of the nutritional content of Malaysian edible bird's nest. Malaysian Journal of Nutrition, 16, 389-396.

Pacheco-Aguilar, R., Mazorra-Manzano, M.A., RamírezSuárez, J.C. (2008). Functional properties of fish protein hydrolysates from Pacific whiting
(Merluccius productus) muscle produced by a commercial protease. Food Chemistry, 109(4), 782789. https://doi.org/10.1016/j.foodchem.2008.01.047

Panyam, D. and Kilara, A. (1996). Enhancing the functionality of food proteins by enzymatic modification. Trends in Food Science and Technology, 7(6), 120-125. https:// doi.org/10.1016/0924-2244(96)10012-1

Paraman, I., Hettiarachchy, N.S., Schaefer, C. and Beck, M.I. (2007). Hydrophobicity, Solubility, and Emulsifying Properties of Enzyme-Modified Rice Endosperm Protein. Cereal Chemistry, 84(4), 343349. https://doi.org/10.1094/CCHEM-84-4-0343

Paydar, M., Wong, Y.L., Wong, W.F., Hamdi, Ahmed Hamdi, O.A., Abd. Kadir, N. and Looi, C.Y. (2013). Prevalence of nitrite and nitrate contents and its effect on edible bird nest's colour. Journal of Food Science, 78(12), T1940-T1947. https:// doi.org/10.1111/1750-3841.12313

Pokora, M. Eckert, E., Zambrowicz, A., Bobak, L., Szoltysik, M., Dazbrowska, A., Chrzanowska, J., Polanowski, A. and Trziszka, T. (2013). Biological and functional properties of proteolytic enzymemodified egg protein by products. Food Science and Nutrition, 1(2), 184-195. https://doi.org/10.1002/ fsn3.27

Raikos, V. (2010). Effect of heat treatment on milk protein functionality at emulsion interfaces. A review. Food Hydrocolloids, 24(4), 259-265. https:// doi.org/10.1016/j.foodhyd.2009.10.014

Roussel, P., Lamblin, G., Lhermitte, M., Houdret, N., Lafitte, J-J., Perini, J-M., Klein, A. and Scharfman, A. (1988). The complexity of mucins. Biochimie, 70 (11), 1471-1482. https://doi.org/10.1016/0300-9084 (88)90284-2

Sathivel, S., Bechtel, P.J., Babbit, J. Prinyawiwatkul, W., Negulescu, I.I. and Reppond, K.D. (2004). Properties of protein powders from arrowtooth flounder (Atheresthes stomias) and herring (Clupea harengus) by-product. Journal of Agricultural and Food Chemistry, 52(16), 5040-5046. https:// doi.org/10.1021/jf0351422

Seena, S. and Sridhar, K.R. (2005). Physicochemical, functional and cooking properties of under explored legumes, Canavalia of the Southwest coast of India. Food Research International, 38(7), 803-814. https://doi.org/10.1016/j.foodres.2005.02.007

Shahidi, F., Han, X.Q. and Synowiecki, J. (1995). Production and characteristics of protein hydrolysates from capelin. Food Chemistry, 53(3), 285-293. https://doi.org/10.1016/0308-8146(95) 93934-J 
Singhal, P., Nigam, V.K. and Vidyarthi, A.S. (2012). Studies on production, characterization and applications of microbial alkaline proteases. International Journal of Advanced Biotechnology Research, 3(3), 653-669.

Souissi, N., Bougatef, A., Triki-Ellouz, Y. and Nasri, M. (2007). Biochemical and functional properties of sardinella (Sardinella aurita) by-product hydrolysates. Food Technology and Biotechnology, 45(2), 187-194.

Sun, S., Yang, T., Lin, Q., Ma, M., Luo, F. and Liu, J. (2013). Effects of two pre-treatment methods on functional properties of egg white protein hydrolysates obtained by pepsin. Advance Journal of Food Science and Technology, 5(8), 1043-1048. https://doi.org/10.19026/ajfst.5.3202

Sze-Tao, K.W.C. and Sathe, S.K. (2000). Walnuts (Juglans regia L): Proximate composition, protein solubility, protein amino acid composition and protein in vitro digestibility. Journal of the Science of Food and Agriculture, 80(9), 1393-1401. https:// doi.org/10.1002/1097-0010(200007)80:9<1393::AID -JSFA653>3.0.CO;2-F

Tavano, O.L. (2013). Protein hydrolysis using proteases: An important tool for food biotechnology. Journal of Molecular Catalysis B: Enzymatic, 90, 1-11. https:// doi.org/10.1016/j.molcatb.2013.01.011

Tsumura, K., Saito, T., Tsuge, K., Ashida, H., Kugimiya, W. and Inouye, K. (2005). Functional properties of soy protein hydrolysates obtained by selective hydrolysis. LWT Food Science and Technology, 38 (3), 255-261. https://doi.org/10.1016/ j.lwt.2004.06.007

Teodorowicz, M., van Neerven, J. and Savelkoul, H. (2017). Food Processing: The Influence of the Maillard Reaction on Immunogenicity and Allergenicity of Food Proteins. Nutrients, 9(8), 835. https://doi.org/10.3390/nu9080835

Wasswa, J., Tang, J., Gu, X.H. and Yuan, X.Q. (2007). Influence of the extent of enzymatic hydrolysis on the functional properties of protein hydrolysate from grass carp skin. Food Chemistry, 104(4), 1698-1704. https://doi.org/10.1016/j.foodchem.2007.03.044

Wong, Z.C.F., Chan, G.K.L., Wu, L., Lam, H.H.N., Yao, P., Dong, T.T.X. and Tsim, K.W.K. (2018). A comprehensive proteomics study on edible bird's nest using new monoclonal antibody approach and application in quality control. Journal of Food Composition and Analysis, 66, 145-151. https:// doi.org/10.1016/j.jfca.2017.12.014

Yew, M.Y., Koh, R.Y., Chye, S.M., Othman, I. and Ng, K.Y. (2014). Edible bird's nest ameliorates oxidative stress-induced apoptosis in SH-SY $5 \mathrm{Y}$ human neuroblastoma cells. BMC Complementary and Alternative Medicine, 14, 391. https:// doi.org/10.1186/1472-6882-14-391 